\title{
Social Skills : learning cycle model and student team achievement divisions (STAD)
}

\author{
Hadis Aditia Muslim ${ }^{1^{*}}$, M. Japar ${ }^{1}$, Durotul Yatimah ${ }^{1}$ \\ Fitriyani Fitriyani ${ }^{2}$ \\ ${ }^{1}$ Universitas Negeri Jakarta \\ ${ }^{2}$ Universitas Pelita Bangsa
}

\section{Article Info \\ Article history: \\ Received Jan $28^{\text {th }}, 2021$ \\ Revised Mar $07^{\text {th }}, 2021$ \\ Accepted Apr 01 ${ }^{\text {st }}, 2021$}

\section{Keyword:}

Learning Cycle

StudentTeamsAchievement

Divisions (STAD)

Social Skills

\begin{abstract}
This study aims to determine the effect of the Learning Cycle learning model and motivation to improve the social skills of elementary school students. This study used the STAD learning model treatment and the Learning Cycle learning model carried out in two different schools with 32 students of each school's research subjects and with the same level, namely the fourth grade of elementary school. Research method This research uses experimental research design with treatment by level $2 \times 2$ design, with the dependent variable in this study is social skills while the independent variable is the learning model with learning motivation. The treatment variables are divided into two, namely the learning cycle learning model and the student teams achievement divisions (STAD) learning model and the high learning motivation variable and low learning motivation. The results of this study indicate that there are differences in the social skills of elementary school students between students learning with the Learning Cycle Model and students learning using the Student Teams Achievement Divisions Model.
\end{abstract}

(C) 2021 The Authors. Published by IICET.

This is an open access article under the CC BY-NC-SA license

(https://creativecommons.org/licenses/by-nc-sa/4.0

\section{Corresponding Author:}

Hadis Aditia Muslim

Universitas Negeri Jakarta

Email: hadisaditiamuslim_7526168289@mhs.ac.id

\section{Introduction}

Today's education is not only focused on improving the academic field alone, but other abilities also greatly contribute to the success of the student learning process. The Learning Cycle and Student Teams Achievement Divisions (STAD) learning model can affect children's learning motivation towards students' social skills. One of the disciplines contained in Elementary Schools is Social Sciences (IPS). The Social Science lesson contains material related to social life and social problems that occur in society and the state government system. Social Science is one of the most important subjects to study because it contains material about social life and all its problems that are adapted to the times, by learning Social Sciences is expected to develop social skills and be able to overcome social problems that will be faced by students. in the future.

As a professional and competent teacher, you must be able to design all efforts in classroom learning, an effective learning model is needed which is expected to improve students' social skills through Social Science lessons. In the learning process, the teacher has a duty to choose the right learning model in accordance with the material to be delivered in order to achieve learning objectives. Therefore, learning must be endeavored to be interesting and enjoyable so that students get an unforgettable learning experience. Being a teacher needs to 
pay attention to good classroom management, especially when discussing to be more intensive in motivating students who do not care so that the implementation of learning activities can take place in accordance with active, innovative, creative, and fun learning (Bachri et al., 2013)

According to Arends quoted by Agus Suprijono, the learning model refers to the approach to be used, including learning objectives, stages in learning activities, learning environment, and class management (Suprijono, 2009). One of the learning models that can be applied to Social Sciences subjects to improve students' social skills is the Learning Cycle Model and the Student Teams Achievement Divisions (STAD) Learning Model, this model emphasizes abilities that are organized in such a way that learners can master competencies. which must be achieved by playing an active role. (Bachri et al., 2013) This model emphasizes the initial concept of students and the application of the knowledge acquired in learning, therefore the Learning Cycle Model and the Student Teams Achievement Divisions (STAD) model are appropriate. implemented in Social Sciences learning in elementary schools to optimize students' social skills.

In addition to the learning model used in Social Sciences learning, learning motivation is also considered influential in the process of improving students' social skills. Motivation to learn is an impetus in students that gives rise to activities and learning directions to achieve the desired goals of students. Motivation to learn is the driving force or impetus that exists in a person both intrinsic and extrinsic which can lead to learning activities, provides direction, ensures learning continuity and plays a role in the development of several positive attitudes, such as excitement, joy in learning so as to increase knowledge and skills with indicators: (1) desire and desire to succeed; (2) encouragement and need in learning; (3) the existence of hopes and aspirations for the future; (4) there is appreciation in learning; (5) there are activities that are interesting in learning; (6) there is a learning environment that is fun for students.

Learning learning cycle affects students' critical thinking skills (Novianti, 2014). The Learning Cycle model for students is a method to be able to process the information obtained through certain phases or stages so that it can become a new knowledge that is expected to stick in their memory. (Results \& Ipa, 2017). It is hoped that every science subject teacher will apply the Learning Cycle learning model to improve student learning achievement (Harefa, 2020). The Learning Cycle (5E) is a student centered learning model, which is a cooperative learning method that has been proven to increase student motivation and learning, in the form of 5 series of stages (phases) organized in such a way, including: engagement, exploration planning, elaboration, and evaluation (Rosa et al., 2017)

Learning Learning Cycle involves three interactions, namely physical knowledge, social knowledge, and self-regulation (Darojat, 2016). Learning with the collaborative method will also be very interesting and what is certain is that the classroom atmosphere will be attractive because the learning atmosphere will involve students being active. Learning Cycle learning and the Student Teams Achievement Division (STAD) method are examples so that students also have motivation for a more enjoyable learning process. Student Teams Achievement Division (STAD) is a method or approach in cooperative learning that is simple and good for teachers who are just starting to use a cooperative approach in class, STAD is also an effective cooperative learning method. STAD-type cooperative learning was developed by Slavin and his friends at John Hopkin University. Teachers using STAD, also referring to student group learning, present new academic information to students each week using verbal or text presentations. The teacher divides the students into small groups consisting of 4-5 people and consists of men and women who come from various tribes, have high, medium, and low abilities.

There is an increase in student learning outcomes after implementing learning with the 7E learning cycle model, with n-gain in all three classes being categorized as very high (Candra, 2017). The STAD learning model is more effective than conventional models in improving social studies learning outcomes (Kristin, 2016) In principle, social studies education in elementary schools does not teach social sciences as a scientific discipline, but rather the essential concepts of social sciences to shape students into good citizens (good citizens). Therefore, as an effort in character building, it is necessary to conform to the culture of this nation (Anshori, 2016) Learning with a process skills approach in the cooperative learning setting type STAD can change learning from teacher center to student centered (Zulhartati, 2011) Active learning is applied with a student-centered approach so that the learning process will take place optimally and be more effective in improving student learning outcomes (Maduretno et al., 2016).

Social skills are abilities that can be obtained through the learning process and habituation, in the development of social skills students can be influenced by three factors that influence them according to (Mulyana, 2014), namely: (1) Internal factors, namely factors that humans have since birth, which includes intelligence, special talents, gender, traits and personality. (2) External factors, namely factors faced by individuals at the time and after birth, exist in the environment including family, school, community, peer 
groups, and the physical environment. (3) Factors obtained when the internal factors are influenced by external factors such as attitudes, emotions, habits and personality. These three factors can influence the development of students' social skills, if internal, external, and both factors support the development of students' social skills, the results achieved by students will be optimal and will be very useful for students' social life in the future. Social skills can not only be developed through materials but also through various methods, media, and evaluations (Maryani \& Syamsudin, 2009).

The social skills possessed by students will make them individuals who can behave in accordance with the demands of their social environment. According to Cavell, McFall and Dubois: . . social skills are presumed to form the foundation for competence in most major models. Once focusing on more molecular and observable units of behavior, more current conceptualizations of social skills, incorporate a full range of cognitive, emotional, and behavioral skills and abilities, as well as motivational and expectancy sets (Nangle et al., 2010) Social skills can form the basis of a model for core competency. After focusing on a broader unit and observing each behavior, the current concept of social skills combines a variety of cognitive, emotional, and behavioral skills and abilities, as well as motivation and expectations. Development of appropriate social skills in children can be seen as a way to prevent of reduce future high risk behaviors, such as poor social interactions, and their negative consequences, such as school failure (Boisjoli \& Matson, 2010)

According to the opinion Social Skills are special abilities that enable competent performance of social situations, including open behavior, social cognitive skills, and emotional regulation. In the learning process too, there must be encouragement from ourselves, we usually call motivation. Motivation is a conscious effort to drive, direct, and maintain a person's behavior so that he is motivated to act to do something so as to achieve certain results or goals (Purwanto, 2017). There is a positive relationship between learning motivation and student learning outcomes and an increase in student motivation on harmonic motion material with a very good category (Candra \& Achmadi, 2017).

Collaborative learning models of social interaction provide solutions to optimize social skills in response to social gaps and social behavior attitudes of learners as well as social symptoms and problems in today's society (Bali, 2017). The use of animation media in social studies learning has a significant effect on student learning motivation (Alannasir, 2016). There are various ways that cooperative learning can be carried out, namely by the existence of cooperative learning which is supported by learning technology innovations such as computers which have very strong cognitive root abilities (Sherman, 2001). "The findings support the theory that students' past learning experiences in science (i.e. conceptions of learning science) affect their motivational beliefs and self-regulation" (Soltani \& Askarizadeh, 2021), that students' learning experiences in science (i.e. conceptions of science learning) influence their motivational beliefs and self-regulation. The results have important implications for the teaching and learning of science. Students who have social skills can be seen from some of the behaviors they do towards their peers and their environment, as for the characteristics of social skills according to (Lesmana, 2015). That social skills and student motivation have a strong relationship (Alpian \& Mulyani, 2020).

\section{Method}

This study uses an experimental research method. The experimental method can be interpreted as a research method used to find the effect of certain treatments on others under controlled conditions (Sugiyono, 2011). This study used an experimental research design with a $2 \times 2$ treatment by level design, with the dependent variable in this study being social skills, while the independent variable was the learning model with learning motivation. The treatment variables are divided into two, namely the learning cycle learning model and the Student Teams Achievement Division (STAD) learning model and the high learning motivation variable and low learning motivation. The research data obtained were quantitative data in the form of students' social skills and a Likert scale from a student learning motivation questionnaire. The affordable population in this study were all fourth grade students of SDN Rawamangun 12, East Jakarta. In the area of Pulogadung, East Jakarta, there are several public elementary schools and they were randomly randomized so that SDN Rawamangun 12, East Jakarta was selected. The instrument testing was carried out at SDN Rawamangun 12, East Jakarta. The sampling technique in this study using simple random sampling technique. The instrument used in this study was a non-test instrument (questionnaire) regarding students' social skills and student learning motivation. The instrument was structured to determine the level of students' social skills and the level of student motivation.

Cooperative learning model with experiential learning approach, can improve students' social skills. (2) Instructional design to improve the social skills of students in learning social study is a model of cooperative learning with experiential learning approach (Indrastoeti \& Mahfud, 2015). 


\section{Results and Discussion}

The data in this research is the skill data of the fourth grade students who have been achieved in the learning process. This ability is obtained through learning indicators that have been made with the dimensions of the process, content and context of the IPS application. The data were obtained through the learning process by applying the learning cycle media model and the Student Teams Achievement Divisions (STAD) model.

Social skills data are obtained after the teacher carries out the learning process by applying a predetermined learning model, assigning assignments and evaluating. The social skills ability test is adjusted to the indicators that have been compiled. The following is a description of the calculated data and the results of the research:

\section{Social Skills for Elementary School Students Who Learn Using the Learning Cycle Model (A1)}

Based on the research data obtained, the social skills score in the group of students is given treatment using the learning cycle model is 17 for the lowest score and 28 for the highest score, then the data is presented in the form of a frequency table as follows the number of classes 6 , with interval length 2, average 23.4 and a standard deviation of 3.1855 , the distribution of social skills scores can be seen in the following table.

Table 1. Frequency Distribution of Social Skills for Elementary School Students Using the Learning Cycle Model.

\begin{tabular}{ccccccc}
\hline No & Score & F & Upper Limit & Lower Limit & Fk & Fr \\
\hline $\mathbf{1}$ & $17-18$ & 2 & 16.5 & 18.5 & 2 & $10 \%$ \\
\hline $\mathbf{2}$ & $19-20$ & 2 & 18.5 & 20.5 & 4 & $10 \%$ \\
\hline $\mathbf{3}$ & $21-22$ & 3 & 20.5 & 22.5 & 7 & $15 \%$ \\
\hline $\mathbf{4}$ & $23-24$ & 4 & 22.5 & 24.5 & 11 & $20 \%$ \\
\hline $\mathbf{5}$ & $25-26$ & 5 & 24.5 & 26.5 & 16 & $25 \%$ \\
\hline $\mathbf{6}$ & $27-28$ & 4 & 26.5 & 28.5 & 20 & $20 \%$ \\
\hline & Amount & 20 & & & & $100 \%$ \\
\hline
\end{tabular}

From the table above, the group of students who study using the Learning Cycle model shows that there are $20 \%$ of students who score in the average class, $35 \%$ of students are below the average class and $45 \%$ of students are above the average class. In the following, the researcher presents a histogram image of the social skills scores of students who learn using the learning cycle media model in the following figure.

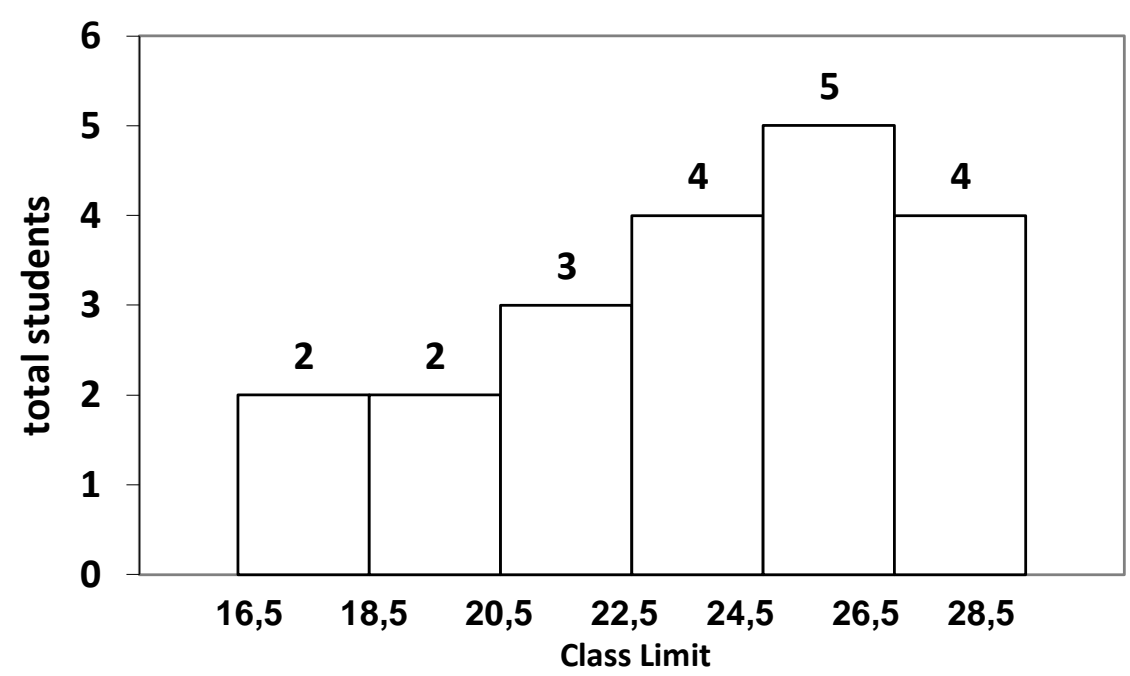

Figure 1. Social Skills Scores of Elementary School Students Using the Learning Cycle Model.

Based on the picture above, the following data can be seen, 2 people for the interval class 17-18, 2 people for the 19-20 interval class, 3 people for the 21-22 interval class, 4 people for the $23-24$ interval class, $25-26$ classes. a total of 5 people, and a class of 27-28 a total of 4 people. The highest frequency score lies in class $25-$ 26 with a total of 5 people or $25 \%$ of the total students and the lowest frequency score lies in classes 17-18 and 19-20 with 2 people or $10 \%$ of the total data. 
Social Skills for Elementary School Students Using the STAD Model (A2).

Based on the research data obtained, the social skills score in the group of students given treatment using the Stad Model is 16 for the lowest score and 26 for the highest score, then the data is presented in the form of a frequency table as follows the number of classes 6 , with interval length 2, average 21,35 and a standard deviation of 2.5149 , the distribution of social skills can be seen in the following table.

Table 2. Frequency Distribution of Social Skills for Elementary School Students Using the STAD Model.

\begin{tabular}{ccccccc}
\hline No & Score & F & $\begin{array}{c}\text { Upper } \\
\text { Limit }\end{array}$ & $\begin{array}{c}\text { Lower } \\
\text { Limit }\end{array}$ & Fk & Fr \\
\hline $\mathbf{1}$ & $16-17$ & 1 & 15.5 & 17.5 & 1 & $5 \%$ \\
\hline $\mathbf{3}$ & $18-19$ & 3 & 17.5 & 19.5 & 4 & $15 \%$ \\
\hline $\mathbf{4}$ & $20-21$ & 7 & 19.5 & 21.5 & 11 & $35 \%$ \\
\hline $\mathbf{5}$ & $22-23$ & 5 & 21.5 & 23.5 & 16 & $25 \%$ \\
\hline $\mathbf{6}$ & $24-25$ & 3 & 23.5 & 25.5 & 19 & $15 \%$ \\
\hline & $26-27$ & 1 & 25.5 & 27.5 & 20 & $5 \%$ \\
\hline
\end{tabular}

From the table above, the group of students who studied with the STAD model showed that there were $25 \%$ of students who got the average class score, $55 \%$ of the students were below the average class and $20 \%$ of the students were above the average class. In the following, the researcher presents a histogram image of the social skills scores of students who learn using the Stad model in the following figure.

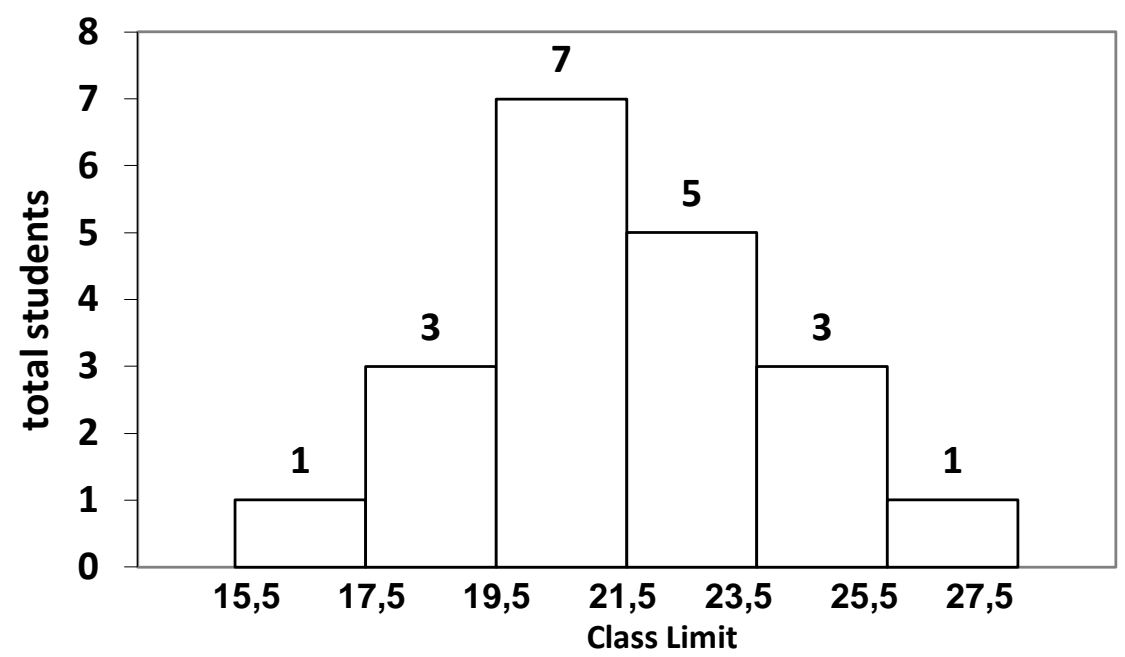

Figure 2. Social Skills Score of Primary School Students Using the STAD Model

Based on the picture above, it can be seen that the data are as follows, interval class 16-17 totaling 1 person, interval class 18-19 totaling 3 people, interval class 20-21 totaling 7 people, interval class 22-23 totaling 5 people, class 24-25 3 people, and 1 class from 26-27. The highest frequency score lies in classes 20-21 with a total of 7 people or $35 \%$ of the total students and the lowest frequency score lies in classes 16-17 and 26-27 with 1 person or $5 \%$ of the total data.

Data on Social Skills of Elementary School Students Who Have High Learning Motivation Ability Using the Learning Cycle Model (A1B1).

Based on the research data obtained, the social skills score in the group of students was given treatment using the Learning Cycle Model is 24 for the lowest score and 28 for the highest score, then the data is presented in the form of a frequency table as follows the number of classes 5 , with interval length 1 , average 26 and a standard deviation of 1.2472 , the distribution of social skills can be seen in the following table 3 . 
Table 3. Frequency Distribution of Student Social Skills with High Learning Motivation Using the Learning Cycle Model.

\begin{tabular}{ccccccc}
\hline No & Score & F & Upper Limit & Lower Limit & Fk & Fr \\
\hline $\mathbf{1}$ & 24 & 1 & 23.5 & 24.5 & 1 & $10 \%$ \\
\hline $\mathbf{2}$ & 25 & 3 & 24.5 & 25.5 & 4 & $30 \%$ \\
\hline $\mathbf{3}$ & 26 & 2 & 25.5 & 26.5 & 6 & $20 \%$ \\
\hline $\mathbf{4}$ & 27 & 3 & 26.5 & 27.5 & 9 & $30 \%$ \\
\hline $\mathbf{5}$ & 28 & 1 & 27.5 & 28.5 & 10 & $10 \%$ \\
\hline & Amount & $\mathbf{1 0}$ & & & & $\mathbf{1 0 0} \%$ \\
\hline
\end{tabular}

From the table 3 , the group of students who have high learning motivation ability using the Learning Cycle Model shows that there are $20 \%$ of students who score in the average class, $40 \%$ of students are below the average class and $40 \%$ of students are above the average class. In the following, the researcher presents a histogram image of the social skills scores of students who learn using the Learning Cycle Model in the following figure.

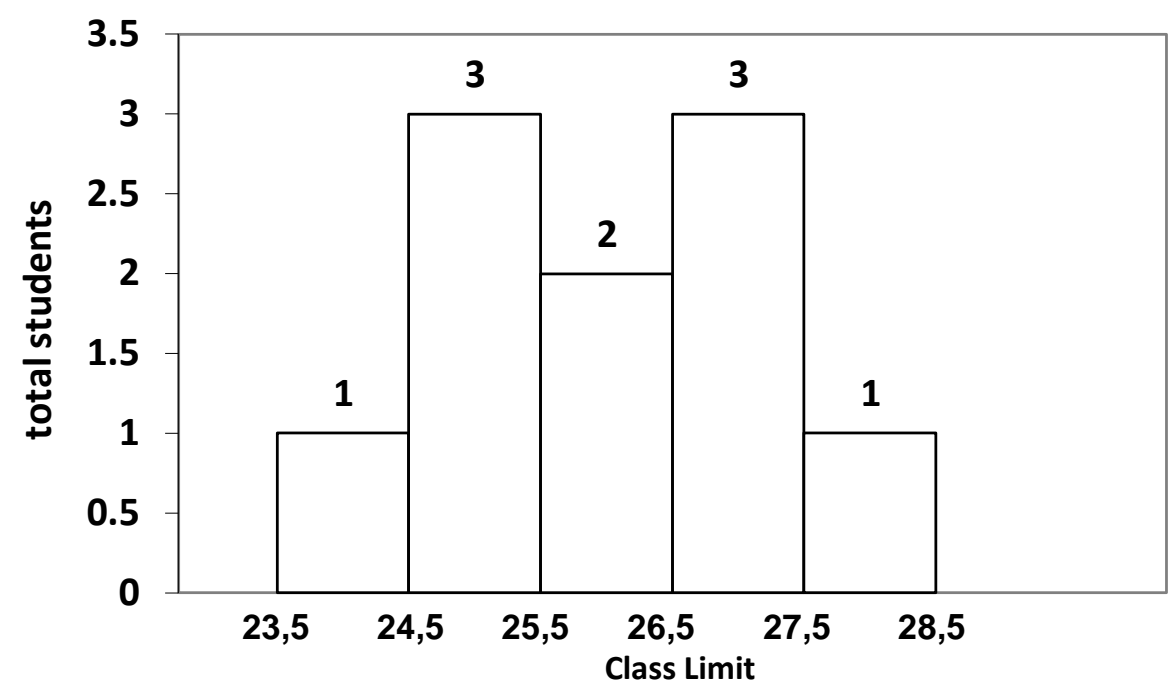

Figure 3. Social Skills Scores of Students with High Learning Motivation Ability Using the Learning Cycle Model.

Based on the picture above, the following data can be seen, the 24 interval class consists of 1 person, the 25 interval class consists of 3 people, the 26 interval class consists of 2 people, the 27 interval class consists of 3 people, and the 28 class consists of 1 person. The highest frequency score lies in classes 25 and 27 with a total of 3 people or $30 \%$ of the total students and the lowest frequency score lies in classes 24 and 28 with a total of 1 person or $10 \%$ of the total data.

Data on Social Skills of Elementary School Students Who Have High Learning Motivation Using the Stad Model (A2B1).

Based on the research data obtained, the social skills score of students who have high learning motivation ability using the Stad Model is 16 for the lowest score and 24 for the highest score, then the data is presented in the form of a frequency table as follows the number of classes 5 , with interval length 2 , average -average 20.4 and a standard deviation of 2.2706, the distribution of social skills can be seen in the following table 4 .

From the table 4, the student's social skills group has High Learning Motivation ability using the Stad Model showing that there are $60 \%$ of students who score in the average class, $20 \%$ of students are below the average class and $20 \%$ of students are above the average class. In the following, the researcher presents a histogram image of the social skills score of students who have high Learning Motivation using the Stad Model in the following figure. 
Table 4. Frequency Distribution of Student Social Skills with High Learning Motivation Using the Stad Model.

\begin{tabular}{|c|c|c|c|c|c|c|}
\hline No & Score & $\mathbf{F}$ & $\begin{array}{l}\text { Upper } \\
\text { Limit }\end{array}$ & $\begin{array}{c}\text { Lower } \\
\text { Limit }\end{array}$ & Fk & Fr \\
\hline 1 & 14-15 & 1 & 13.5 & 15.5 & 1 & $10 \%$ \\
\hline 2 & $16-17$ & 1 & 15.5 & 17.5 & 2 & $10 \%$ \\
\hline 3 & $18-19$ & 6 & 17.5 & 19.5 & 8 & $60 \%$ \\
\hline 4 & $20-21$ & 1 & 19.5 & 21.5 & 9 & $10 \%$ \\
\hline 5 & $22-23$ & 1 & 21.5 & 23.5 & 10 & $10 \%$ \\
\hline
\end{tabular}

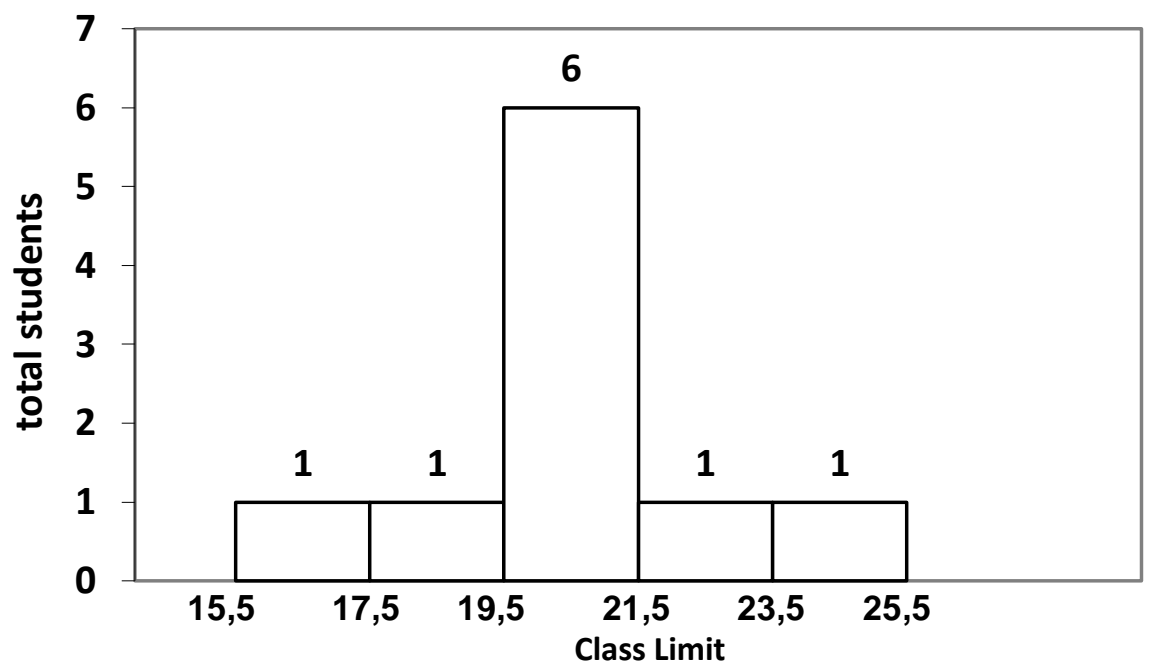

Figure 4. Social Skills Scores of Elementary School Students Who Have High Learning Motivation Using the Stad Model.

Based on the picture above, it can be seen that the data are as follows, interval class 16-17 totaling 1 person, interval class 18-19 totaling 1 person, interval class 20-21 totaling 6 people, interval class 22-23 totaling 1 person, and class 24- 25 in the amount of 1 person. The highest frequency score lies in class 20-21 with a total of 6 people or $60 \%$ of the total students and the lowest frequency score lies in classes 16-17,18-19,22-23, 24-25 with 1 person or $10 \%$ of the total data.

\section{Conclusion}

Based on the purpose of this study that the study wanted to determine the effect of learning models and learning motivation of elementary school students on the skills of elementary school students. The learning models used are Learning Cycle and STAD. The data analysis in this study is the normality test and the homogeneity test of the data.

Based on the results of the analysis and discussion described in this study, the following conclusions can be drawn (1) the difference in learning motivation between children using the learning cycle learning model and children using the STAD learning model. Empirical evidence through this research shows that the score of learning motivation of elementary school students in students who learn using the learning cycle learning model is higher than students who learn using the STAD learning model. Thus, efforts to increase learning motivation of elementary school students by paying attention to students' social skills can be pursued by providing a learning cycle model of learning as a social studies learning process in elementary schools. (2) the influence of the interaction between the learning cycle learning model and learning motivation on social skills. Based on statistical analysis regarding the skills of elementary school students which are mutually influenced by two independent variables in this study, namely, the learning cycle learning model and learning motivation cause an interaction effect. (3) Increasing the social skills of elementary school students who have high learning motivation through the learning cycle model. Empirical evidence through this study shows that for students who have high learning motivation, the social skills of students who learn using the learning cycle 
learning model integrated into social studies learning in elementary schools are proven to be higher than students who learn using the STAD learning model. Thus, efforts to improve the social skills of elementary school students by taking into account student learning motivation can be pursued using the learning cycle model as a learning process that is integrated into the social studies learning process in elementary schools. (4) Increasing social learning skills of elementary school students who have low learning motivation through the STAD learning model. Empirical evidence through this study shows that for elementary school students who have low learning motivation, the social skills of students who learn using the STAD learning model integrated into social studies learning in primary schools are proven to be higher than students who learn using the learning cycle learning model. Thus, efforts to improve the social skills of elementary school students by taking into account students' low learning motivation can be pursued by using the STAD learning model as a learning process that is integrated into the social studies learning process in elementary schools.

\section{References}

Alannasir, W. (2016). The influence of the use of animation media in social studies learning on the learning motivation of students in grade IV SD Negeri Manado. Journal of Educational Science and Technology (EST), 2 (2), 81-90.

Alpian, Y., \& Mulyani, R. (2020). Relationship between social skills and student motivation. Cakrawala Pendas Journal, 6 (1).

Anshori, S. (2016). Contribution of Social Sciences in Character Education. Edueksos: Journal of Social \& Economic Education, 3 (2).

Bachri, S., Universitas, P. G., \& Malang, N. (2013). Application of cycle learning learning models to improve student's reasoning ability. Unnes Physics Education Journal, 2 (1), 268-272. https://doi.org/10.15294/upej.v2i1.2934

Bali, M. M. E. I. (2017). Social interaction model in elaborating social skills. Pedagogy: Journal of Education, $4(2)$.

Boisjoli, J. A., \& Matson, J. L. (2010). General methods of assessment. In social behavior and skills in children (pp. 61-75). Springer.

Candra, I. A. (2017). 7E Learning Cycle Learning Model to Increase Student Motivation and Learning Outcomes in Class X Harmonic Motion Material at SMAN 1 Kejayan. Physics Education Innovation, 6 (3).

Candra, I. A., \& Achmadi, R. (2017). 7E Learning Cycle Learning Model to Increase Student Motivation and Learning Outcomes in Class X Harmonic Motion Material at SMAN 1 Kejayan. Journal of Physics Education Innovation (JIPF), 06 (03), 83-90. https://jurnalmahasiswa.unesa.ac.id/index.php/inovasipend Pendidikan-fisika/article/view/20092

Darojat, L. (2016). Unnes Journal of Mathematics Education Research Resolving Open Ended Problems Based On Aq With Learning Cycle 7E Abstract. 5 (1), 1-8.

Harefa, D. (2020). Improving Students' Science Learning Achievement in Learning Cycle Model with Energy and Change Material. Trapsila: Journal of Basic Education, 2 (01), 25-36.

Hasil, T., \& Ipa, B. (2017). The effect of cycle learning model on the results of studying IPA Agus Jatmiko 1) 1). $8(1), 53-65$.

Indrastoeti, J., \& Mahfud, H. (2015). Cooperative Learning With Experiental Learning Approach To Improve Social Skills. Elementary School Platform, 2 (2), 140-151.

Kristin, F. (2016). The Effectiveness of STAD Cooperative Learning Model in terms of Social Studies Learning Outcomes of Grade 4 Elementary School Students. Scholaria: Journal of Education and Culture, 6 (2), 74-79.

Lesmana, A. (2015). The Effect of the Application of the Type STAD Cooperative Learning Method on Social Skills and Critical Thinking Ability of Elementary School Students in Social Studies subjects. Indonesian education university.

Maduretno, T. W., Sarwanto, S., \& Sunarno, W. (2016).

Maryani, E., \& Syamsudin, H. (2009). Development of a Social Studies Learning Program to improve social skills competencies. Research Journal, 9 (1).

Mulyana, U. (2014). Improving students 'cooperative learning results and social skills in IPS lesson through the implementation of the jigsaw type cooperative learning model. Indonesian education university.

Nangle, D. W., Erdley, C. A., Adrian, M., \& Fales, J. (2010). A conceptual basis in social learning theory. In Practitioner's guide to empirically based measures of social skills (pp. 37-48). Springer.

Novianti, A. (2014). The effect of the learning cycle learning model on students' critical thinking skills. Edusains, 6 (1), 109-116.

Purwanto, M. N. (2017). Educational Psychology. Bandung: Youth Rosdakarya. 
Rosa, E., Gayatri, P., Bahar, A., \& Handayani, D. (2017). Comparison Of The Application Of Learning Cycle (5e) And Two Stay Two Stray Learning Models Abstract Number of students Results of pretest meetings 1 Results of pretest meetings 2 Results of posttest meetings 1 Results of posttest meetings 2 Average pretest Mean posttest Difference. 1 (1), 71-74.

Sherman, L. W. (2001). Chapter 6 - Cooperative Learning and Computer-Supported Intentional Learning Experiences. In C. R. B. T.-L. and T. on the W. W. Wolfe (Ed.), Educational Psychology (pp. 113-130). Academic Press. https://doi.org/https://doi.org/10.1016/B978-012761891-3/50009-6

Soltani, A., \& Askarizadeh, G. (2021). How students' conceptions of learning science are related to their motivational beliefs and self-regulation. Learning and Motivation, 73, 101707. https://doi.org/https://doi.org/10.1016/j.lmot.2021.101707

Suprijono, A. (2009). Cooperative learning: PAIKEM theory \& application. Student Libraries.

Zulhartati, S. (2011). STAD cooperative learning model in social studies subjects. Building Teacher, 26 (2) 